\title{
A representation of a Tuawhenua worldview guides environmental conservation
}

\author{
$\underline{\text { Puke Timoti }}^{1}$, $\underline{\text { Philip O'B Lyver }}^{2}, \underline{\text { Rangi Matamua }}^{3}$ Christopher J. Jones $^{2}$ and Brenda L. Tahi ${ }^{1}$
}

\begin{abstract}
Indigenous peoples and local communities interact with approximately two-thirds of the world's land area through their worldviews and customary tenure regimes and offer significant knowledge contributions and lessons about sustainability. We worked with Tuawhenua Māori to document domains, concepts, and mechanisms within the worldview representation in a way that could guide environmental conservation in New Zealand. We then applied the framework to a cultural keystone species for Tuawhenua, the kereru ([New Zealand pigeon [(Hemiphaga novaeseelandiae]) to elucidate this human-environment relationship. Whakapapa (genealogy), whenua (land), and tangata (people) were interconnected domains that formed the conceptual basis of our framework. Within these domains, the concepts of mauri (life essence), mana (authority), and ihi (vitality) guided the expression of the community's relationship with the environment. Cultural expressions related to the kererū demonstrated the cultural significance of the bird to Tuawhenua that went well beyond the ecological and intrinsic value of the species. The Tuawhenua worldview representation also emphasized the humannature relationship and the role that metaphor plays in expressing this relationship. Indigenous peoples and local community worldviews are important for establishing priorities, reconciling the human relationship with the environment, and facilitating the coproduction of knowledge in response to pressing local and global environmental conservation issues.
\end{abstract}

Key Words: environmental conservation; indigenous peoples; kererū; Māori; worldview

\section{INTRODUCTION}

The worldviews of indigenous peoples and local communities (IPLCs) are important for environmental conservation and management globally. Indigenous peoples and local community worldviews offer alternative perspectives centered on the quality of the human-environment relationship compared with worldviews that are dominant in modern societies and which are often materialistic and dualistic and assume the superiority of humankind (Van Opstal and Hugé 2013). Indigenous peoples and local communities interact with approximately two-thirds of the world's land area through their customary tenure regimes (AldenWily 2011, Rights and Resources Initiative 2015, Brondizio and Le Tourneau 2016) and offer valuable approaches and knowledge contributions to environmental sustainability (Tengö et al. 2017). The diversity of customary regimes is characterized by highly context-specific worldviews and knowledge systems (Johnson et al. 2016). The ability for IPLCs to express their worldviews through customary tenure regimes, however, is often confounded by the governments of countries that do not formally recognize IPLCs as having common ownership or statutory control over their lands, which may be as little as $5 \%$ of the land area in many countries (Rights and Resources Initiative 2015). Consequently, the institutions and common law that affect the presence and actions of people on these lands frequently reflect the worldviews and priorities of the ruling governments rather than those of the IPLCs (West et al. 2006, Lyver and Tylianakis 2017, Ruru et al. 2017). These fundamental differences in worldviews are creating increasing conflict as degradation of land, isolation from lands, and pressures over natural resources mount (Craig et al. 2012).

Worldviews can be defined as coherent collections of value orientations and cognitive maps that allow people to orient and make sense of their world (Aerts et al. 1994, Vidal 2008, van Egmond and de Vries 2011, Van Opstal and Hugé 2013). As defined by Haverkort and Reijntjes (2007:431), "a worldview (or cosmovision) is the way a certain population perceives the world (or cosmos). It includes assumed relationships between the human world, the natural world and the spiritual world. It describes the perceived role of supernatural powers, the relationship between humans and nature, and the way natural processes take place." Worldviews represent the ethical basis, principles, and assumptions around which people and populations organize themselves to interact with nature (Allport 1935, Haverkort and Reijntjes 2007). All humans are subject to different environmental conditions and behave within different contexts; therefore, "culture" as a factor exerts a major influence on worldviews and attitudes (Van Opstal and Hugé 2013).

While the legal recognition of land rights remain outstanding around the world, efforts to recognize IPLC rights in some countries have facilitated the rise of goals within contemporary environmental conservation systems to implement customary worldviews and tenure regimes (Berkes 2010). The fundamental weakness in this paradigm shift is that the worldviews governing institutions and technologies remain largely those of industrialized western governments and seldom represent those of the IPLCs (Mistry and Beradi 2016). Despite the rights of IPLCs being enshrined within the constitutions, policy, and common law of some countries, asymmetries in environmental governance and management remain (Brondizio and Le Tourneau 2016). Furthermore, problems related to the identification and use of effective methods for bridging a diversity of worldviews and indigenous knowledge systems have emerged from these processes (Agrawal 2002, Raffles 2002, Stevenson 2006), although conceptual and institutional approaches to mitigate these issues are well described internationally (Davies et al. 2013, Tengö et al. 2014, Rathwell et al. 2015). Indigenous peoples and local community worldviews also typically guide 
action at local levels, so are seldom applied at national or international scales (Walsh et al. 2013). Therefore, the capacity of government frameworks to engage indigenous peoples' worldviews, including their values, knowledge, approaches, and cultural expressions, remains challenged (Houde 2007, Ens et al. 2015).

Notwithstanding the issues, the need to engage IPLC worldviews as guides for "weaving diverse knowledge systems" to achieve methods and effective outcomes for people and the environment remains (Johnson et al. 2016, Tengö et al. 2017). Exposure to, and insights into, these worldviews would also provide actors who are responsible for institutions and technologies with a better understanding of "alternative ways of knowing" (Dods 2014), which would aid cross-cultural learning (Walsh et al. 2013). The objective of this study, therefore, was to represent a worldview of a Māori tribal group, Tuawhenua, in New Zealand in a way that could guide environmental conservation and land management. We describe and translate the core domains, concepts, and mechanisms that inform a representation of a Tuawhenua worldview. We then use Tuawhenua cultural expressions that are relevant to the kererū (New Zealand pigeon [Hemiphaga novaeseelandiae]) to demonstrate the applicability of this worldview representation. Finally, we discuss the need to reframe governance and related policy mechanisms to facilitate the expression of IPLC worldviews and strengthen cultural integrity as part of environmental conservation.

\section{METHODS}

\section{Describing the Tuawhenua worldview}

We documented a worldview representation by using a two-stage process in working with Tuawhenua elders and forest users from the Māori community of Ruatāhuna. Ruatāhuna is located in the heavily forested Te Urewera mountain ranges of New Zealand's North Island and consists of approximately 72 households clustered around 10 traditional marae (meeting places) (Morunga and Tahi 2013) (Fig. 1). The first stage involved constructing a preliminary worldview representation through one-on-one meetings with a subgroup of eight tribal elders ( $n=15$ meetings; range $=1-4$ hours long). The worldview representation was updated iteratively through this series of meetings. The second stage involved using two one-day workshops, mostly with elders but also with some younger members from the Tuawhenua community, to further critique and verify the representation. The first workshop was attended by 13 participants (mean age: 60 years; age range: $39-80$ years); the second was attended by 11 participants (mean age: 67 years; age range: $57-80$ years). Both workshops were conducted primarily in the Māori language. Dialogue at both the meetings and workshops revolved around the definition and explanations of the domains and concepts within the worldview, mechanisms that linked the structure of the worldview, and the applicability of worldview in the context of Tuawhenua.

\section{Engaging Tuawhenua knowledge of the kererū}

To explore the function of the Tuawhenua worldview representation as it related to the kererū, we used indigenous knowledge contained within interviews conducted with elders and forest users in the community between 2004 and 2014. The kerer $\bar{u}$, a fruit pigeon, was abundant historically within Te Urewera forests and was a significant source of food and feathers for Tuawhenua. Despite its population decline over the last 75 years (Lyver et al. 2008), it still holds significant cultural value for the Tuawhenua people. A purposive semidirected approach was used to interview participants (Huntington 2000, Telfer and Garde 2006). Although some participants lived outside Ruatāhuna at the time of their interview, all were originally from the community. Most interviews were conducted in the Māori language and were transcribed and translated into English before being verified by Tuawhenua researchers who were fluent in the local dialect.

Fig. 1. Location of the Tuawhenua region and community of Ruatāhuna within the forested mountainous region of Te Urewera on the North Island of New Zealand.

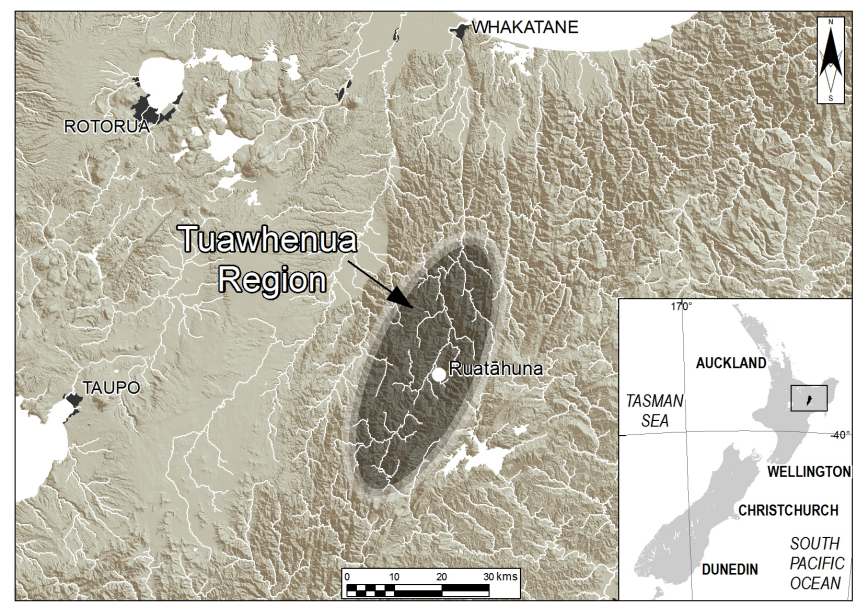

The first round of interviews (Mātauranga o te kerer $\overline{\mathrm{u}}$ - Traditional knowledge of the kererū) was conducted between 2004 and 2007 and focused on the biocultural context of kererū and the forest for Tuawhenua. We interviewed 10 male elders (mean age: 62 years; age range: $50-84$ years) who were identified as having knowledge pertaining to the kereru. The second round of interviews (Mātauranga ō te Tuawhenua - Traditional knowledge of the Tuawhenua) was conducted between 2011 and 2012 and focused on oral histories related to the use of forest resources (e.g., the kerer $\overline{\mathrm{u}})$ by community members $(n=18$ participants; mean age: 66 years; age range: 49-79 years). Lastly, the third round of interviews (Mātauranga o te taiao - Traditional knowledge of the environment) was conducted with Tuawhenua elders and forest users between 2013 and 2014. These interviews focused on the connection between the community and the forest, and on trends and changes in biodiversity $(n=39$ interviews [three interviews were conducted with two or more participants present]: 29 male participants, 14 female participants; mean age: 58 years; age range: $18-82$ years).

Validity was assessed using convergent triangulation (Creswell and Miller 2000) between Tuawhenua interview narrative, documentary, and artistic cultural expressions related to the kererū. Cultural expressions pertaining to the kererū came from unpublished Tuawhenua literature and traditional art works. A workshop with Tuawhenua elders and forest users $(n=11$ participants; mean age: 67 years; age range: $57-80$ years) was used 
to augment and verify the accuracy and context of narrative related to the kererū as well as alignment to the worldview categories.

\section{Ethical approval for the research}

This study emerged from discussions between researchers and the Tuawhenua community as part of a 15-year forest research initiative. As a first step, the concept was formally introduced to the Tuawhenua community through a series of meetings and workshops. Guidelines and ethical approval to conduct the research were considered and approved as part of a Memorandum of Understanding between the host research institute, Landcare Research, and the Tuawhenua. In addition, a signed cultural safety agreement between individual researchers and Tuawhenua detailed obligations regarding prior and informed consent, intellectual property and ownership of traditional and scientific knowledge, confidentiality, reporting back to the community, process for the release of results and breaches of the agreement, and researcher accountability to the Tuawhenua community. Two of the authors of this paper are Tuawhenua.

\section{RESULTS}

Core domains, concepts, and mechanisms within a representation of a Tuawhenua worldview

The Tuawhenua worldview representation was constructed around three domains broadly described as whakapapa (genealogy), whenua (land and environment), and tangata (people) (Fig. 2). Interlocking concepts of mauri (life force), mana (authority), and ihi (vitality) were constructed within the domains of whenua and tangata, which were linked together by mechanisms of tapu (sacredness or to be placed under restriction) and wairua (spiritual essence) (Fig. 2).

Whakapapa: Tuawhenua participants interpret whakapapa broadly as "genealogy" and consider it to be a sequential system that portrays the interconnectedness between all elements of the living and nonliving realms. Whakapapa connects Tuawhenua with their ancestors and defines their obligations to their environment. It is also interpreted as "origins" that binds the heavens to the earth. It is the root term for raupapa, denoting the order or layering of elements culminating in creation. A thorough understanding of whakapapa is considered by Tuawhenua elders to be pivotal to understanding their ideology and connection with the environment.

"Be watchful that you do not harm your elder Tāne" (god of the forest; the originator of people and the forest) (Wharehuia Milroy 2016, Mātauranga o te taiao meeting, Rotorua).

Whenua and Tangata: The importance of whenua (land) and the plants and animals upon it has a significant link to the domain of whakapapa (Fig. 2). Tuawhenua participants locate themselves as being part of the whenua and the living whakapapa of that environment. In the context of this study, whenua encapsulates land, as well as the environment that nurtures and nourishes people. Whenua also translates as the placenta that sustains the baby through pregnancy. The essence of the word symbolizes the connection Tuawhenua have with their land. Tangata is translated as "people," including individuals, families, subgroups, and communities (Fig. 2).
Fig. 2. Tuawhenua worldview built around the three key domains of whakapapa (genealogy), whenua (land and environment), and tangata (people), and its function governed by the concepts of mauri (life force), mana (authority), and ihi (essential energy, feeling, and emotion).

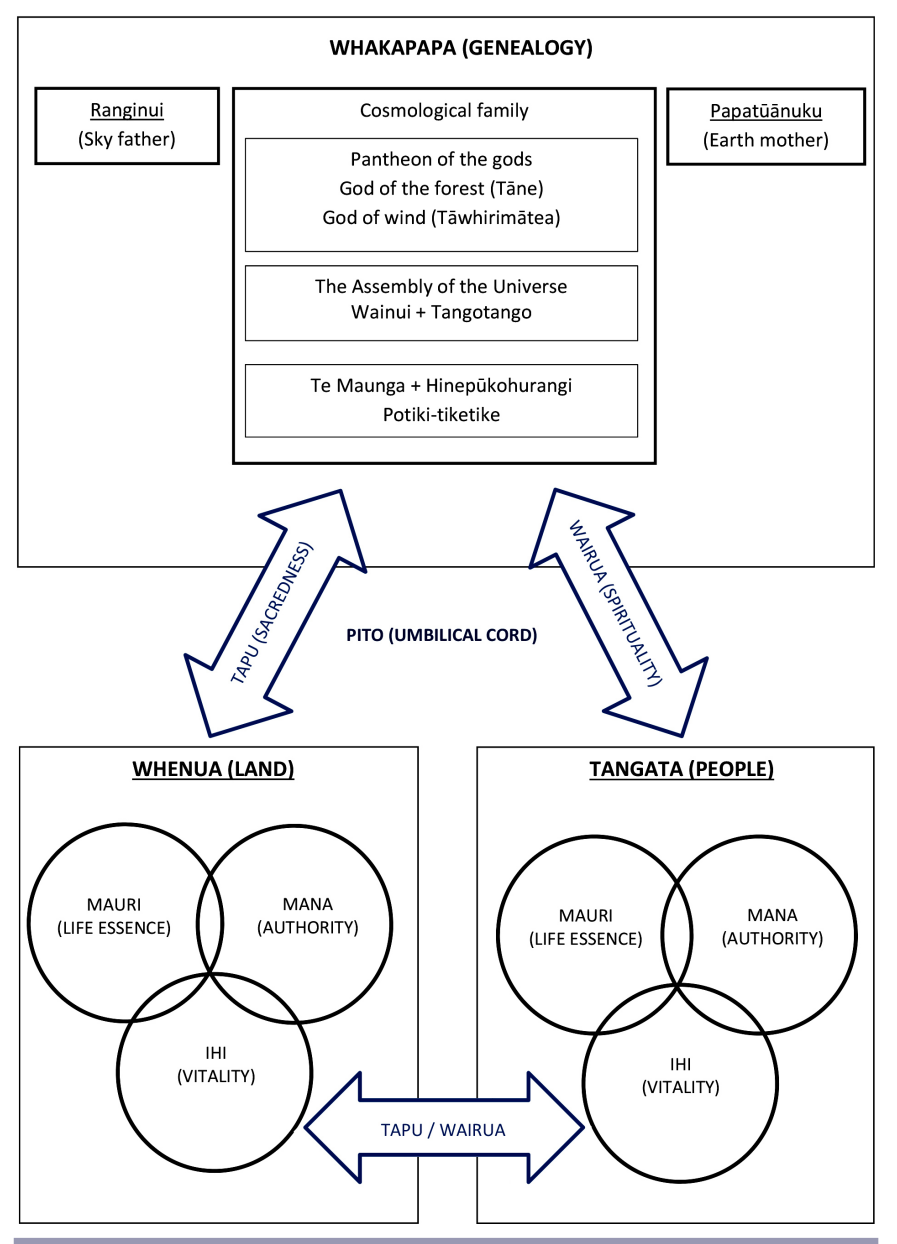

Mauri: Tuawhenua participants describe mauri as life essence or life force which is linked intrinsically to whakapapa. It is a concept that describes the representativeness and condition of the relationships and responsibilities between elements of whakapapa. Mauri denotes the interconnectedness and appropriate sequential order of elements within whakapapa. Tuawhenua recognize that people have a critical role to protect the mauri of the environment. They also acknowledged that everything has a mauri, and that at times it can be invoked or instilled into someone or something to maintain the set of obligations within the whakapapa.

"You hold the life essence. That is your role - to maintain the vitality within your world" (Te Mahururangi Te Kawa 2015; Mātauranga o te taiao interview; translated from Māori, Ruatāhuna).

Mana: Mana was acknowledged by Tuawhenua participants as being authority and prestige that is derived from within the domain of whakapapa and the relationships that exist through this sequential order. Tuawhenua describe everything as having mana, 
although the degree of mana assigned to a person, object, or entity could vary. The notion of mana can be inherited, and it provides a person with an unbroken link to their past and connects them to their future. It was also recognized that mana could be earned and acquired by an individual or grouping of people throughout the course of their lives. Participants reported that virtually every aspect of an activity had a link with the maintenance and enhancement of mana, which meant that it was also linked closely to the concept of mauri.

Ihi (wehi and wana): Tuawhenua participants recognize ihi as the vitality or energy that emulates from places, items, people, and significant events. For example, ihi can be felt on occasions when practitioners deliver outstanding cultural performances. It can also exist within an inanimate object or landmarks that are believed to be imbued with their own power. Tuawhenua recognize that the concepts of $i h i$, wehi, and wana could operate as single emotions or together as an assemblage. Wehi is a response to $i h i$ and means to be "in awe" or overcome with admiration, reverence, or fear. It is also described as an emotional reaction to the acknowledgement of ihi. Wana is interpreted as the inspirational force and is the result of combining ihi and wehi. It is a heightened emotional state that unites a range of emotions and connects people to place, objects, landmarks, and other people. Collectively, ihi, wehi, and wana are used by Tuawhenua to gauge the vitality of the mauri and the mana within the whenua and tangata domains.

"Te ihi, te wehi, te wana. Those are your emotions. Those are your indicators in a Māori worldview to assess the vitality of the mauri and the mana. When you travel in different areas you feel the essential energy" (Te Mahururangi Te Kaawa 2015; Mātauranga o te taiao workshop; translated from Māori, Ruatāhuna).

Tapu and wairua: The mechanisms of tapu and wairua are integral to the function of the worldview representation. Tapu is expressed by Tuawhenua as being something that is set apart, sacred, or forbidden with an untouchable quality. It was described as having innate qualities, drawing those from its origins within whakapapa. Participants recognize that applying tapu places animate or inanimate objects under restriction, therefore often imbuing those objects with mana or a greater level of reverence. The function of tapu was to provide boundaries and protect the mana and mauri of a place, object, time, species, person, or people. Tuawhenua participants also recognize that tapu is pivotal for understanding and exercising wairua. Wairua is described as the spiritual essence or soul carried within a person (or other life forms) that is released usually at the point of death, or sometimes during sleep. It also refers to an unseen realm that connects the person with the past, the present, and the future. The metaphor of the pito (umbilical cord) in the worldview representation is used to denote the conduit for infusing the three domains with wairua, which is governed by tapu.

"Тари is a tool to place a protective cover over something you treasure. It provides protection for a resource when not in use so it be utilized at a later date"(Te Rongonui Tahi 2015; Mātauranga o te taiao wānanga; translated from Māori, 27 June 2015, Ruatāhuna).

"Wairua is intangible. You know that it is there or it exists but you can't touch it or see it" (Tangiora Tawhara, Mātauranga o te taiao 2015, Ruatāhuna).
Function of a Tuawhenua worldview representation: a case study of the kererū

Function of the Tuawhenua worldview representation was exemplified through the relationship of Tuawhenua with the culturally significant bird species, the kererū(Table 1). Tuawhenua participants spoke about the forests of Te Urewera being renowned historically for the abundance of kererū and the community for its ability to provide the bird as a revered food. Kererū represents a shared identity for both the land and people (Table 1). It is regarded by Tuawhenua to be a manu rangatira (noble bird) within the whakapapa of the forest with significant mana and therefore holds a status above other birds in the forest. Names of places in the forest and other forest species reflect their relationship with the kereru (Table 1). The elevated position of the kererū within Tuawhenua whakapapa meant that it was considered to be imbued with significant mauri, which is reflected in the $i h i$ associated with the bird (Table 1).

"No sooner had I finished my prayers I heard this thundering coming up the valley like a jet and I thought, 'Oh! I'm in trouble here.' Then I heard this sound, 'Whoooooosh!!!' By crikey, the trees are moving and they were quite a distance away when they turned around and it was white everywhere. There was a constant cooing all over the place. I was in awe and shivering with fear. I was so afraid I could feel my hairs standing. Some time went by and my excitement finally settled" (Poai Nelson; Mātauranga o te Tuawhenua 2011, translated from Māori, Ruatāhuna).

The $i h i$ or the emotion that emanated from experiencing large flocks of kereru $\mathrm{u}(300+$ birds) congregating in the forest during the autumn to feed on the fruit of the toromiro (Prumnopitys ferruginea) is reported by Tuawhenua elders to reflect the health and vibrancy of the mauri in the forest (Table 1). Arrival of these immense flocks into the forest would elicit an intense emotional response in a hunter. Over the last 75 years, however, the kererū population has undergone an extensive decline, which has affected the mana of the whenua (Te Urewera) as a stronghold for kererū, and tangata (Tuawhenua people) as stewards of these birds.

The elevated status of the kererū also meant that consumption of the bird historically was often restricted to occasions of significance, and the bird was served mainly to guests and individuals of high rank within the tribe (Table 1). Garments (e.g., korowai [traditional cloak]) made from the feathers of kererū were generally reserved for women of high-ranking status (Table 1); however, this changed the nature of the woman's relationship with the bird.

"The high-ranking women that wear the precious cloaks made of kerer $\bar{u}$ feathers to enhance and wrap around one's body do not eat the kererū. Eating the kereru lifts the tapu from the person so they become 'common' (noa); however, if the person wears a cloak of kereru feathers this makes the person highly revered (tapu) with respect to the kererū. So therefore this is why lore exists. The cloak made of kerer $\bar{u}$ feathers is made of just kererū feathers and nothing else. Since the kereru $\bar{u}$ is so revered, feathers from other birds are not used. This is why women of high status that wear cloaks made of kererū feathers do not eat kererū" (Moai Tihi, Mātauranga o te kererū interview, 14 April 2004, Tāneatua).

The importance of wairua and tapu within kererū harvest practices was emphasized by Tuawhenua (Tables 1, 2, and 3). Historically, strict observances around kerer $\bar{u}$ harvest practices and protocols 
Table 1. Examples of cultural expressions (as they relate to a cultural keystone bird species, the kererū, [New Zealand pigeon, Hemiphaga novaeseelandiae]) contained within the conceptual domains (whakapapa - genealogy; whenua - land; tangata - people) and concepts (mauri-life force; mana - authority; ihi-vitality) of a Tuawhenua worldview representation. As portrayed in Fig. 2, the domains and concepts are not mutually exclusive but rather overlap and interact with each other constantly.

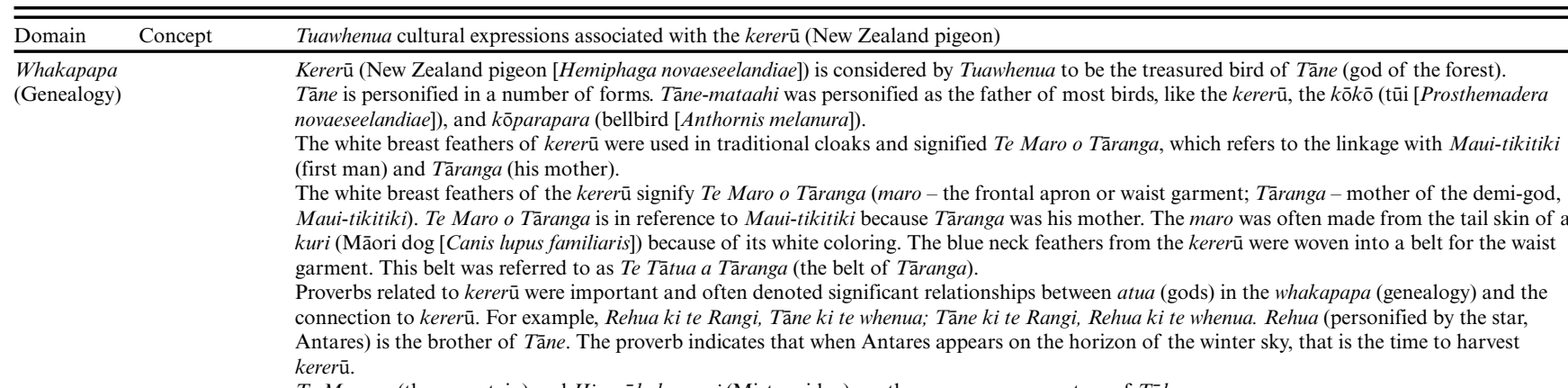

Te Maunga (the mountain) and Hinepūkohurangi (Mist maiden) are the eponymous ancestors of Tūhoe.

Whenua Mauri Respect for the kawa (rules) and tikanga (etiquette) related to the kererū were paramount. To preserve the integrity of the kererū, an individual's (Land) (Life essence) manner and way of thinking had to change while harvesting, preparing, and eating kererū.

Practices that protect the mauri of the kererū included bringing the first birds harvested back to the ahi tapu (sacred fires) where they would be cooked and served to women.

Strict season for harvest, governed closely by an tohunga (expert or priest), protects the mauri of the kereru.

At times the mauri of the kereru is held back by Tāne, and therefore requires a tohunga to invoke the mauri, using ceremony and ritual so the hunters can take a harvest.

The thundering sound from the flocks of kereru heard in the forest during the day represents the presence of mauri.

Karakia (prayers) were conducted at the tipapa rākau (trees where kererū perched) to draw in the kererū.

Kererū were harvested primarily by men, but those women who participated in the harvest forfeited their rights to eat the bird

An abundance of taumatua (perches) in the forest signifies abundance of kererū and vitality of the forest and bird.

A booming sound sometimes heard in the forest at night is the departure of the mauri of the kererū. This signifies there has been a transgression

against the rules and protocols associated with respecting and safeguarding the kererū.

The practice of inserting kereru tail and wing feathers into the ground and then covering them over with leaf litter and soil denotes a mark of respect or practice of maintenance toward the mauri of the bird.

Leaving evidence of the kill (e.g., blood, feathers, or innards) lying around in the forest violates the mauri of the kererū, which other kererū can sense, so make themselves unavailable.

The decline in kererū abundance has been attributed to Tāne taking back the mauri of the kereru from man and no longer replenishing it because Tuawhenua were no longer harvesting the bird (because of government laws). The mauri of the kereru has been returned to a higher power than a human organization.

Kerer $\bar{u}$ have a critical role in maintaining the mauri of the forest because they are the only remaining forest bird species with a gape large enough to swallow and disperse some of the larger fruits (and seeds).

Whenua Mana Kererū is a mōkai (highly significant species) for Tuawhenua. It is considered to be Te kura huna o Tāne (the hidden treasure of Tāne) because of its (Land) (Authority) sometimes cryptic behavior.

Kerer $\bar{u}$ is put up above all the other bird species in status because of its abundance and importance to people and the forest.

The kererū is considered to be a manu rangatira (chiefly bird) species because of its historical abundance in the forest and important role in feeding and clothing women, esteemed guests, and high-ranking individuals in the tribe.

Specific ceremony and customary regulations for harvesting, processing, and eating denotes the status of the kereru. Harvesting and processing is done in a special way not normally reserved for other species (e.g., to avoid defiling the mana of the kererū, feathers are not left scattered around forest floor, rather birds are brought back to the community for plucking and consumption).

Only specially selected hunters can participate in the harvesting of kererū.

Specific observances and practices for the eating of the kereru (e.g., breaking open of the bird was an honored and privileged role; there is an appropriate ritualistic method for breaking open the bird once its cooked; the kererū is not eaten at night).

Kererū is not eaten as a regular daily meal; instead, it is reserved for special occasions, such as the opening of wharenui (ancestral house), whare karakia (church), or whare kai (dining house). Kererū is not a common everyday food like chicken.

High-ranking women who wear the kererū korowai (feather cloak) do not eat the kererū. Wearing of the cloak around the body makes the person tapu (sacred), while eating of the kererū makes them noa (common).

Hunters needed to refrain from being whakamomoko (obstinate) toward the kererū if the flocks came late or were small. Hunters never boasted about the number of kereru they were planning to harvest. This is the respect accorded to the mana of kererū.

You do not process or eat kererū with utensils because it is disrespectful to poke at something of such elevated importance.

The traditionally weaved mat upon which kererū were piled and plucked was burnt once plucking was completed to preserve the mana of the bird. Names of species and locations reflect association with and importance of the kereru.

The native conifer, toromiro (Prumnopitys ferruginea), is named after the way the kereru is required to stoop or extend its neck to feed on its fruits (toro - to stoop or extend; miro - the fruit).

Tarapounamu is the location where a pounamu (jade) spear-tip belonging to Tamatea-kai-taharua broke off in a kereru when it was lanced. The wounded bird was tracked and finally caught at a place called Pūtauaki.

Te Kohuru Tukuroa: This site is a long ridge adjacent to the Whakatane River where extensive snaring of kererū occurred.

Tapuikakahu is a name of a particular toromiro above Hanamahihi on the Whakatane River. It was named after an act by a Tühoe ancestor who came across some kererū caught in snares. He cast his kākahu (cloak) over the birds to claim them for himself (tapui).

Te Angawhakatangitangi is a sacred cave at Maungapohatu where the karakia (ceremonial prayers) were conducted to open the season for harvesting kerer $\overline{\mathrm{u}}$.

Te Weraiti umu tahu noa is a reknown Ruatāhuna harvest location for kererū prior to it being milled. The name literally translates as "the ovens at Te Weraiti are always burning."

Te Uru-taumatua is the post-settlement entity for the Tühoe tribe; the naming is a reference to the strength and sustenance this tree provides to prosper. Uru is a grove of trees, and taumatua applies to a tree much resorted to by kererū, often referred to as rakau tipapa-tree perch of the kererū. 
Whenua Ihi The sound of a large kererū flock (300+ birds) arriving was akin to a passenger jet flying into the valley. The experience would chill you and raise (Land) (Vitality) the hairs on your neck.

The alighting of a large kereru flock (300+ birds) settling into the trees was like snow across the canopy and left you in awe.

The constant "rustling" of the forest canopy caused by kererū moving around would be unnerving.

Tangata Mauri $\quad$ Karakia was used prior to kererū harvest to (1) prepare hunters for the task ahead, (2) acknowledge the significance of Tāne and the kererū, and

(People) (Life essence) (3) maintain and prolong the harvest opportunity.

Tohunga (expert, specialist, or priest) or special person of influence was responsible for maintaining, or if kererū were scarce, invoking the mauri of the kererū.

Eating of the kererū by pregnant women transferred the mauri of the bird to the unborn baby.

Kaumātua (elders) will offer prayers to the gods (to the unseen) so that the hunters can wave away any obstacles or bad omens and achieve the correct observances to allow the hunt to proceed safely and easily.

Tuawhenua tohunga and/or kaumātua used karakia (prayer) prior to the serving and eating of the kererū to ensure the mauri of the kererū remained with them, thereby allowing only the physical form of the bird to be given to other tribes. This practice warded against the mauri of the kereru departing with any visitors.

Hunters needed to be matakite or in the right frame of mind and single-minded about their purpose while harvesting kererū.

Community members cared for and prepared kererū as if it was their own heart. When kererū was distributed to chiefs, it was given as if it were a person's own heart. This sealed the end of an individual's responsibilities for nurturing the bird.

Connections between tribes were founded upon the mauri of the kererū. Historically, there has been a rivalry between Tuawhenua and Tūwharetoa (a neighboring tribe) over holding the mauri of the kererū. If the kererū were absent from Tuawhenua lands, the mauri for the bird was considered to be held by Tūwharetoa. Tuawhenua tohunga would then use traditional incantations to recapture the mauri from Tūwharetoa.

Partaking of kererū encapsulates the relationship with the people. "We are what we eat." Tuawhenua recognized that they are part of the makeup

of the forest environment. To consume kererū, in essence is re-establishing that link inwardly (to attain the attributes of Tāne).

Tangata Mana Provision of kererū as food demonstrates your skills and capacity as kaitiaki (environmental guardian) to care for the current and future

(People) (Authority) prosperity of the environment.

Revered kaumātua or tohunga are tasked with holding the mana and mauri of the kererū.

Mana comes from being able to provide kererū as food for high-ranking visitors.

Decline in kererū populations is attributed to government usurping the mana for the kererū and forest from Tuawhenua.

The elevated importance and significance of rangatira (chiefs) and women within Màori society means they are given the best parts of the bird

(breast, thighs, and posterior of the bird) to eat. Men are given the bones, claws, and soup to eat.

The eating of the kereru symbolized the significance of the spiritual domain. This was the spirit taken by the tribe during those times of

harvesting.

Korowai (traditional cloaks) made from kererū feathers were worn by māreikura (noble women) or a hautipua (high-ranking women).

Eating of the kererū by chiefs, women, and esteemed visitors is an expression of the link to Täne. The kererū was considered the best of the foods, so the practice gives mana to the visitors by showing them that they are respected and important. No other food that could do that.

Prior to serving kererū at a significant occasion, the puha haka hari kai (a ceremonial dance) would be performed to ensure that the mana (and mauri) of the kererū remained with the local people.

Harvesting sites or territories for kererū associated with specific subtribes and families were fiercely defended by the mana whenua (local people).

Tangata Ihi Prior to serving huahua (preserved kererū) at a significant occasion, the puha-haka hari kai (a ceremonial song and dance) would be performed to

(People) (Vitality) acknowledge the abundance of food and that the time of fasting was over. This tribute to the kereru was conducted largely by women and could be highly charged and suggestive because it linked the fertility of the land and people. As the huahua was laid on the table, those women participating in the puha-haka hari kai would take a small amount of oil and rub it into their hair to raise the mana of the kereru and to prevent others'

admirations of the kererū. The puha-haka hari kai process also safeguarded against visitors uplifting the mana and mauri of the kererū when they departed after the feast.

Homage to the place or site where kererū were harvested was always paid by visiting chiefs.

Boundary violations and transgressions infuriated local people, so threat of retaliation maintained the $i h i$, including wehi and wana).

Transgression against rules and guidelines was avoided through the maintenance of ihi, wehi, and wana (e.g., timing of the harvesting season was very strict; a hunter would not eat during the process of harvesting kererū).

Unusual behavior or events associated with the kererū were interpreted as acknowledgement of the relationship between the bird and people. For example, in 1987, more than 300 kererū were observed clinging to the wall of a cliff in Waikaremoana during a visit of Tūhoe kaumātua to a sacred cave. This event was interpreted as recognition of the people's relationship to this particular site.

(e.g., karakia [prayer and incantations]; cooking of the first kererū harvested in ahi tapu [sacred fires]) infused the process with wairua and lifted tapu. Tuawhenua recognized that these processes were used to protect the mauri of the forest and kereru in order to guarantee a good harvesting season (Table 1). Similarly, strict observances were also adhered to during the harvest itself (Table 1). The practices were used to re-establish the link to Tāne (god of the forest) through the kererū. Karakia by tohunga (specialist or expert) would establish the connection and acknowledge the mana of Tāne and of the forest (Tables 1 and 2). These practices were enacted to entice Tāne to pour out his abundance and enhance the $i h i$ of the forest so that the harvest of kereru by the community would be bountiful.

"Rawiri Te Kokau was the last tohunga (specialist) to enact this practice in 1925. They (tohunga) would climb to the top of Maungapohatu (Tūhoe's sacred mountain) to the caves that the tohunga of ancient times would visit to open the bounty of Tàne (god of the forest), Te Pua nui o Tāne" (Pou Temara, Mātauranga o te taiao meeting, 25 August 2014, Ruatāhuna).
“In 1972, Te Kaaho, John Rangihau's uncle and others were still alive and a ceremonial feast was called, which was held with the people of Te Wai-iti. The purpose of the feast was to take back the life force of the bird to Tāne (god of the forest). The birds (kerer $\bar{u})$ were harvested and the table was set, and the prayers began. And it was upon those elders who were responsible for returning the life force of the birds back to Tāne" (Peho Tamiana, Mātauranga o te kererū interview; 22 April 2004, Ruatoki).

Tuawhenua participants reported that when an individual ate kererū, they were partaking in the mauri and mana of Tāne (Tables 1,2 , and 3). The notion that "you are what you eat" encapsulates the relationship with Tāne, not only as the symbol of the kererū, but as Tāne, the representative of the forest in its entirety. The attributes of Tāne could also be transferred to an unborn child if a woman ate kererū while pregnant. Waiata (traditional songs), mōteatea, karakia, and haka (ceremonial song and dance) were conducted to acknowledge the fundamental relationship the Tuawhenua people had with the kererū by capturing their history and relationship with the bird and its environment (Tables 1, 2, 3 , and 4). The haka kererū (also referred to as the puha-haka hari 
Table 2. Traditional Tuawhenua karakia (prayer and incantation) was used to entice the mauri (life force) and vitality of the kereru (New Zealand pigeon [Hemiphaga novaeseelandiae]), thereby maintaining its relationship with the people and ensuring its presence within the community. This example is one of many incantations and practices that were traditionally observed by Tuawhenua to reaffirm the unique relationship with the kererū. These acts are remembered in song and verse, and are painted on the rafters of traditional Tuawhenua meeting houses.

\begin{tabular}{ll}
\hline \hline Te Reo Māori version & English version \\
\hline Hoki mai, hoki mai & Return, return, \\
Hoki mai ki to urunga & Return to your abode \\
Ki to moenga & To your place of rest \\
Ki te paepae tapu a Tāne. & To the sacred perch of Tāne \\
Hoki mai te manu ora ki te & Return the vitality of this bird to the \\
maunga koia e... & mountains \\
E ko ko koia e... & And there remain. \\
\hline
\end{tabular}

Table 3. A Tuawhenua mōteatea (lament) relevant to the kererū (New Zealand pigeon [Hemiphaga novaeseelandiae]) that was delivered after formal speeches on the marae (traditional meeting place). This complete version was sourced from a private collection of traditional Tūhoe songs by the Reverend Wharetini Rangi family of Tūhoe, and was interpreted by Te Hauauru TahiRangihau and translated by Puke Timoti.

\begin{tabular}{ll}
\hline \hline Te Reo Māori version & English version \\
\hline Tçnā koutou te hua mai na! & Greetings to you who have me in your \\
Kai te ūhia to kiri kanohi-e & thoughts! \\
Kai te matatū tonu hia nei-e & My eyes are covered in shame \\
He manu maunu au kai te tao & Restless I lay \\
Nā Te Kurapa i whakatoro rā & Like a wounded pigeon \\
To kaihua kai Manuruhi rā & Taken on the end of the spear of Te \\
E kōpae rawa ake i te whare & Kurapa \\
Ko au kai raro tihāea e au & On the tree perch at Manuruhi where \\
He mangareka tōtoro mai ra & birds are plenty \\
I te wā rā kai puhou ana & Restlessness is my abode \\
Ka haramai tçnei ka takoto & I am like discarded food \\
Ka pae taunoa ahau kai te & A desired delicacy once \\
whare! & in the time of my youth \\
Te waka ia rā e te kōrero & Here I lay in waste \\
E waiho i roto tohu mai ai & In the solitude of my house! \\
Kai kaihoko koe i ahau & In a night vision I see \\
Rere ana rā ki ngā hōrire & The signs of your coming \\
Ka tū tonu au i te tohu & My heart is torn asunder \\
hei rāhui tapu & Unable to be hidden within \\
Ki te whanga ko Tara-mai- & Thou painfully affected me \\
nuku & Dedicated and set aside, \\
Moea iho nei ahau & at the foot of Tara-mai-nuku, \\
Ko Te Ihuwaka - kei ahau tonu & I lay sleeping \\
Oho rawa ake nei ki te ao & Alas! Te Ihuwaka is still with me \\
Mapu kau au - ki taku & Then I awake to the world \\
moenga-e & Sobbing - in my place of rest \\
\hline
\end{tabular}

kai - a ceremonial Tuawhenua song and dance associated with the kerer $\bar{u}$ ) (Table 4) would be performed as huahua (preserved kererū) was served to esteemed guests and was used to acknowledge the seasonal abundance of food. The huahua was a highly nutritious, sought-after delicacy, but was presented through the haka kererū as the simplest of food the tribe had to offer. Serving huahua in this way honored the kerer $\bar{u}$ and visitors, which in turn elevated the mana of the local people. It also ensured that the mana and mauri of the kererū remained with Tuawhenua. Most importantly, the haka kerer $\bar{u}$ served to make the connection between the environment and the people, and points to the fundamental platform of life and existence-Papatūānuku (Mother Earth) (Tables 1 and 4). Concern was expressed by Tuawhenua participants that the loss of kererū had weakened these practices and their connection with the bird and forest.

"The women perform the haka while carrying the plates of huahua (preserved kererū) right up to the traditional meeting house and when they get there the plates are placed onto the table and the man who did the opening call would invite everyone to the feast. The elderly women I'm talking about were from Te Wai-iti, Tiripou, and Te Ao. They were so beautiful when they performed by lifting their hips and bottoms in a semigyrating fashion and when they finished the haka it completed the saying, 'Tāne's (god of the forest) blessing on the traditional meeting house - the house of Tāne Whakapiripiri-is complete"' (Poai Nelson, Mātauranga o te Tuawhenua interview, 26 September 2011, Ruatāhuna) (Tables 3 and 4).

"This and the next generation can't comprehend the true meaning of what it means to perform such a haka (puha haka hari kai) (Table 4) because there is nothing tangible. We don't physically do that haka anymore because our relationship with the kererū has waned" (Tangiora Tawhara, Mātauranga o te taiao interview, 22 January 2014, Ruatāhuna).

\section{DISCUSSION}

Reconciling the separation of people from the environment In countries with colonial histories, indigenous peoples frequently confront challenges to their cultural identity, traditional knowledge, and customary environmental stewardship responsibilities (Turner et al. 2008, Tauli-Corpuz 2016). As a result, western environmental worldviews, values, attitudes, and laws often dominate management (Stocker et al. 2016). Increased political capacity and recent advances in legislative mechanisms that support indigenous rights and return of lands offer potential for leadership by, and participation of, indigenous peoples in environmental conservation (Pitty and Smith 2011, Lyver et al. 2014, Ens et al. 2015) (e.g., the Te Urewera forest mountain ranges were accorded with "all the rights, powers, duties, and liabilities of a legal person" [Te Urewera Act 2014, section 11, New Zealand Government 2014]). Giving effect to conceptual constructs and management approaches defined by indigenous worldviews and knowledge systems, however, continues to contrast with and challenge the prevailing management frameworks of western and industrialized nations (Smith 2012, Walsh et al. 2013).

Subversion of traditional Māori laws and treaty rights by the colonial government in New Zealand imposed an alternative worldview of the environment. The process whereby the mana of the environment has been usurped by the European government 
Table 4. Versions of the haka kererū (also known as a puha-haka hari kai, a specific form of Tuawhenua ceremonial song and dance) would be performed with the serving of the huahua (preserved kererū [New Zealand pigeon, Hemiphaga novaeseelandiae]) at special events to emphasize and reinforce the relationship of the people with the bird and forest. Metaphor associated with the haka kererū linked the bountifulness of nature with fertility of the women and the future well-being of the tribe. Individuals tailored different versions of the haka kererū according to different dialects in their local area and their interpretation of the significance.

\begin{tabular}{|c|c|}
\hline Te Reo Māori version & English version \\
\hline \multicolumn{2}{|l|}{ Version 1} \\
\hline Ka aroha te puke e tu iho nei & I am saddened by the hills that surround me \\
\hline Ka horehore, ka horehore & They are barren, they are barren \\
\hline Ka aroha te puke e tu iho nei & I am saddened by the hills that surround me \\
\hline Ka horehore, ka horehore & They are barren, they are barren \\
\hline He aha i hore ai? & Why is it so bare? \\
\hline He kore kai pea & Perhaps because there is no food to be had \\
\hline A me aha? & What shall we do? \\
\hline Me kai pea ko nga raho o (name of the local or visiting chief) & Let's consider eating the testicles of (name of the local or visiting chief) \\
\hline Ka horehore, ka horehore & They are barren, they are barren \\
\hline Ā neke neke hia & Alas, keep moving, keep moving \\
\hline$\overline{\mathrm{A}}, c$. & Alas \\
\hline \multicolumn{2}{|l|}{ Version 2} \\
\hline He kumara kai hamuhamu & Only the fernroots remain \\
\hline Ko te ehu o te kupu nei na & The essential word implies \\
\hline Kia hoki kau atu, ina te tinaki & That we return to till the soil \\
\hline Taia mai, ka mate, taia mai & We haul it back, no good, we haul it back \\
\hline Ka horehore, ka horehore & Absolutely barren, absolutely barren \\
\hline Ka mate te puke tu iho nei & The hills beyond me are barren \\
\hline Ka horehore, ka horehore & Absolutely barren, absolutely barren \\
\hline He kotahi te kete i kimihia & We have only but one basket \\
\hline Kei te kore, kore rawa aku iwi & There was virtually nothing for my people \\
\hline Ki te mahi kai $-i$ & To prepare for a feast. \\
\hline \multicolumn{2}{|l|}{ Version 3} \\
\hline Ka mate te puke e tu iho nei & The hills beyond me are barren \\
\hline Ka horehore, ka horehore & Absolutely barren, absolutely barren \\
\hline Ka mate te puke e tu iho nei & The hills beyond me are barren \\
\hline Ka horehore, ka horehore & Absolutely barren, absolutely barren \\
\hline Nekenekehia, nekenekehia & Keep moving, keep moving \\
\hline $\begin{array}{l}\text { E koro (name of the local or visiting chief) tūpou to ua ki te } \\
\text { ngahere kia mau mai te } k \bar{u}-k \bar{u} \text {, te ku, }\end{array}$ & $\begin{array}{l}\text { Esteemed elder (name of the local or visiting chief) stoop down to the forest, and } \\
\text { bear witness to the } k \overline{\mathrm{u}}-k \overline{\mathrm{u}} \text {, te } k \overline{\mathrm{u}} \text { (sweet sound of the kererū }\end{array}$ \\
\hline Kia mau mai te $k \bar{u}-k \bar{u}$, te $k u$ & Bear witness to the $k \overline{\mathrm{u}}-k \overline{\mathrm{u}}$, te $k \overline{\mathrm{u}}$ (sweet sound of the kerer $\overline{\mathrm{u}}$ ) \\
\hline Nekenekehia, nekenekehia & Keep moving, keep moving \\
\hline He kōkō kei runga kei te toromiro e tūnou ana & There the $t \bar{u} \bar{i}$ sings and nods perched in the toromiro tree \\
\hline$K \bar{u}, k \bar{u}, k \bar{u}$ & $K \bar{u}, k \bar{u}, k \bar{u}$ \\
\hline \multicolumn{2}{|l|}{ Version 4} \\
\hline Ka aroha te puke e tu iho nei & I am saddened by the hills that surround me \\
\hline Ka horehore, ka horehore & They are barren, they are barren \\
\hline He kotahi te mea i kimihia i te korekore rawa & I have secured this mere morsal \\
\hline Taku iwi, ki te mahi kai e & For my people to prepare a feast \\
\hline Aha pakōkō, aha pakōkō & It has shrivelled, It has shrivelled \\
\hline Aha ka pakōkō nga raho o (name of the local or visiting chief) & The testicles of (name of the local chief) have all but shrivelled \\
\hline Aha pakō $k \overline{0}$ & It has all dried up \\
\hline
\end{tabular}

is linked by some Māori to the loss of native biodiversity in New Zealand. Ongoing declines in kererū populations within Te Urewera following the implementation of harvest prohibition law was interpreted as the mauri of the kererū being removed by Tāne since the bird was no longer being used by the people (Lyver et al. 2009). European prohibition laws usurped the mana of the tribes and chiefs, which were perceived to have disrupted and severed the linkages between the domains and core concepts of the Tuawhenua worldview. These laws effectively removed the local Māori communities from their roles and responsibilities in protecting their environment. The re-establishment of these connections is perceived as the first step to restoring not only the health of the environment but also the well-being of the community. An indigenous worldview representation that emphasizes the importance of whakapapa is more likely to reconcile the separation of people (tangata) from the environment (whenua).

Our goal was to represent a Tuawhenua worldview in a way that could guide comprehension of its relevance and application within environmental conservation. The Tuawhenua participants in this study emphasized unequivocally that they would not assume their worldview represented other Māori tribes or indigenous cultures outside of New Zealand. Rather, it was a representation of a framework that consisted of domains, 
concepts, and mechanisms that other Māori tribes might recognize, relate to, and organize in a way that suited their own circumstances. Here, the Tuawhenua worldview emphasizes the multifaceted connections the community has with its environment through whakapapa. Recognized within this whakapapa structure is the subordinate role people have with the environment. This tenet is defined by an ethic of reciprocity and care of your elders, including those "elders" within the plant and animal kingdoms. It ensures that people acknowledge their responsibilities to the environment and behave in a manner that safeguards the integrity of the natural world. In this role, people draw their mana and mauri directly from the well-being of the land and environment. The vibrancy of an ecosystem's mauri increased the likelihood that other key values (e.g., identity, food security, spiritual wellbeing) and opportunities for cultural expression were supported. Failure to foster these connections can be detrimental not only to the maintenance of cultural integrity but also to the essential wellbeing of a people.

\section{Biodiversity is more than just food}

The cultural expressions outlined in this study have been integral to fostering the Tuawhenua peoples' history, language, and relationship with the kerer $\bar{u}$ and forest. These expressions were often crafted to maintain humility and remind the community of the responsibilities the people had to the environment. In some instances, interpretation required a deeper understanding beyond the literal meaning of the words used. The haka kererū (Table 4) linked the bountifulness of nature with fertility of the women and the future well-being of the tribe. It also was a point of reference for a period of Tuawhenua history when the tribe was suffering the impacts of the "scorched earth" policies of the colonizing European government. While wording within the haka kererū can be translated directly with reference to crops being destroyed and hills being devoid of food, the "barren hill" also refers to the woman's mons pubis and the virility of the men and women in the tribe (Table 4).

Stories, oral history accounts, or cultural expressions are common media for portraying a message or lesson in preliterate societies around the world and were often used to guide and alter behavior related to species or the environment (e.g., Berkes 2008). Metaphors take on different forms and have been used in a variety of ways by societies to understand the human-environment relationship (Roberts 2012, Raymond et al. 2013). Cultural metaphors found within expressions like the haka kererū were used by Māori to signify the importance of the species or a resource to the people, but also to reinforce the mana of a tribe as an environmental steward. Similarly, Māori ancestral sayings guided customary management of plants and animals (e.g., flax [Phormium tenax] cultivations) (Wehi 2009). These forms of oral history practice reinforced the knowledge and relationship that a group might have with an animal, plant, or habitat, but can also provide a collective memory of the tribe's history. They also served to reinforce social-ecological strategies for managing the environment. Explicit consideration of metaphors in management systems offers a useful mechanism to assist indigenous, and also nonindigenous, communities with their connection to, interpretation of, and response to, issues confronted in the environment (Raymond et al. 2013, Walsh et al. 2013).

\section{CONCLUSION}

The diversity of IPLC worldviews offers a range of ways of thinking about, relating to, and valuing, the environment. Current environmental ideologies conform largely to the agendas and approaches of western industrialized societies (Lyver and Tylianakis 2017), which creates few opportunities for worldviews of IPLCs to be expressed. In addition, IPLCs in some countries are increasingly under pressure to adjust their worldviews to fit market-based ideals and attitudes toward natural values (Adamowicz et al. 1998, Venn and Quiggan 2007, O'Faircheallaigh 2013). How to engage a range of IPLC worldview representations in national- and international-scale environmental conservation processes and structures without their institutionalization is problematic for governments (Mistry and Berardi 2016). The worldviews of indigenous cultures offer different priorities and approaches to environmental stewardship, and in some instances, will challenge the prevailing conservation management systems (e.g., prioritization of species and habitats in assigning conservation effort and funding). By placing people within conservation action in accordance with an indigenous worldview, both biological and cultural outcomes are emphasized. This approach also conforms to social-ecological systems theory where people are an integral part of ecosystems rather than external agents (Gunderson and Holling 2002, Berkes 2004, Folke 2006). Reforms to environmental conservation policy and systems that support IPLC leadership and participation are therefore needed to engage those groups more effectively in responses to local and global environmental issues (Mazzocchi 2006, Tester and Irniq 2008, Beddoe et al. 2009, Ens et al. 2015). Expression of these worldviews will contribute to "legitimacy, credibility, and saliency" associated with mobilization of indigenous and local knowledge and the positioning of knowledge types alongside each other (Tengö et al. 2017). Such reformed frameworks would also provide a basis for making informed and inclusive decisions about environmental conservation issues (e.g., prioritization of species for conservation action and/or funding). Policy and institutional reforms emerging from land claim and treaty settlements or participatory governance and community-based approaches to planning and management are evolving pathways in some countries (Kearney et al. 2007, Smyth 2008, Davies et al. 2013, Ruru et al. 2017). It is from these social-ecological relationships that the diverse and comprehensive knowledge systems required for protecting and enhancing ecological and cultural diversity and well-being will emerge.

Responses to this article can be read online at: http://www.ecologyandsociety.org/issues/responses. php/9768

\section{Acknowledgments:}

We thank the Tuawhenua elders and community members who participated in and contributed to this study. The drafting of our worldview benefited from the advice of Tahae Doherty, Wiremu Doherty, Dr. Wharehuia Milroy, Tangiora Tawhara, Te Mahururangi Te Kaawa, Prof. Pou Temara, and Kirituia Tumarae. Moehau Kutia, Te Peeti (Spady) Kutia, Te Motoi 
Taputu, Tangiora Tawhara, June Tihi, and Kirituia TumaraeTeka contributed to the collection, translation, and transcription of interviews. Anne Sutherland constructed our location map. The study was conducted under the directorship of the Tuhoe Tuawhenua Trust and was funded by MBIE grants (C09X0308; C09X1307) and Crown Research Institute "Maori and Biodiversity" core funding. Thanks to the editor and two anonymous referees for their review of this article.

\section{LITERATURE CITED}

Adamowicz, W., T. Beckley, D. Hatton Macdonald, L. Just, M. Luckert, E. Murray, and W. Phillips. 1998. In search of forest values of indigenous peoples: Are nonmarket valuation techniques applicable? Society \& Natural Resources 11:51-66. http://dx.doi.org/10.1080/08941929809381061

Aerts, D., L. Apostel, B. De Moor, S. Hellemans, E. Maex, H. Van Belle, and J. Van der Veken 1994. Worldviews: from fragmentation to integration. VUB Press, Brussels, Belgium.

Agrawal, A. 2002. Indigenous knowledge and the politics of classification. International Social Sciences Journal 54:287-297.

Alden Wily, L. 2011. The tragedy of public lands: the fate of the commons under global commercial pressure. International Land Coalition, Rome, Italy.

Allport, G. W. 1935. Attitudes. Pages 798-844 in C. Murchison, editor. Handbook of social psychology. Clark University Press, Worcester, Massachusetts, USA.

Beddoe, R., R. Costanza, J. Farley, E. Garza, J. Kent, I. Kubiszewski, L. Martinez, T. McCowen, K. Murphy, N. Myers, Z. Ogden, K. Stapleton, and J. Woodward. 2009. Overcoming systemic roadblocks to sustainability: the evolutionary redesign of worldviews, institutions, and technologies. Proceedings of the National Academy of Sciences of the United States of America 106:2483-2489. http://dx.doi.org/10.1073/pnas.0812570106

Berkes, F. 2004. Rethinking community-based conservation. Conservation Biology 18:621-630. http://dx.doi.org/10.1111/ j.1523-1739.2004.00077.x

Berkes, F. 2008. Sacred ecology. Second edition. Routledge, New York and London.

Berkes, F. 2010. Devolution of environment and resources governance: trends and future. Environmental Conservation 34:489-500. http://dx.doi.org/10.1017/S037689291000072X

Brondizio, E. S., and F-M. Le Tourneau. 2016. Environmental governance for all. Science 352:1272-1273. http://dx.doi. org/10.1126/science.aaf5122

Craig, D., L. Yung, and W. Borrie. 2012. "Blackfeet belong to the mountains": hope, loss, and Blackfeet claims to Glacier National Park, Montana. Conservation \& Society 10:232-242. http://dx. doi.org/10.4103/0972-4923.101836

Creswell, J. W., and D. L. Miller 2000. Determining validity in qualitative inquiry. Theory into Practice 39(3):124-130. http://dx. doi.org/10.1207/s15430421 tip3903 2

Davies, J., R. Hill, F. J. Walsh, M. Sandford, D. Smyth, and M. C. Holmes. 2013. Innovation in management plans for community conserved areas: experiences from Australian indigenous protected areas. Ecology and Society 18(2):14. http://dx.doi. org/10.5751/ES-05404-180214

Dods, R. R. 2014. Knowing ways/ways of knowing: reconciling science and tradition. World Archaeology 36:547-557.

Ens, E. J., P. Pert, P. A. Clarke, M. Budden, L. Clubb, B. Doran, C. Douras, J. Gaikwad, B. Golt, S. Leonard, et al. 2015. Indigenous biocultural knowledge in ecosystem science and management: review and insight from Australia. Biological Conservation 181:133-149. http://dx.doi.org/10.1016/j.biocon.2014.11.008

Folke, C. 2006. Resilience: the emergence of a perspective for social-ecological systems analyses. Global Environmental Change 16:253-267. http://dx.doi.org/10.1016/j.gloenvcha.2006.04.002

Gunderson, L. H., and C.S. Holling, editors. 2002. Panarchy: understanding transformations in human and natural systems. Island Press, Washington, D.C., USA.

Haverkort, B., and C. Reijntjes, editors. 2007. Moving worldviews. Reshaping sciences, policies and practices for endogenous sustainable development. Compas series on worldviews and sciences 4. ETC/Compas, Leusden, Netherlands.

Houde, N. 2007. The six faces of traditional ecological knowledge: challenges and opportunities for Canadian co-management arrangements. Ecology and Society 12(2):34. http://dx.doi. org/10.5751/ES-02270-120234

Huntington, H. P. 2000. Using traditional ecological knowledge in science: methods and applications. Ecological Applications 10:1270-1274. http://dx.doi.org/10.1890/1051-0761(2000)010[1270: UTEKIS]2.0.CO;2

Johnson, J. T., R. Howitt, G. Cajete, F. Berkes, R. Pualani-Louis, and A. Kliskey. 2016. Weaving indigenous and sustainability sciences to diversify our methods. Sustainability Science 11:1-11.

Kearney, J., F. Berkes, A. Charles, E. Pinkerton, and M. Wiber. 2007. The role of participatory governance and community-based management in integrated coastal and ocean management in Canada. Coastal Management 35:79-104. http://dx.doi. org/10.1080/10.1080/08920750600970511

Lyver, P. O’B., M. Taputu, S. T. Kutia, and B. Tahi. 2008. Tūhoe Tuawhenua mātauranga of kererū (Hemiphaga novaseelandiae novaseelandiae) in Te Urewera. New Zealand Journal of Ecology 32:7-17.

Lyver, P. O’B., C. Jones, and J. Doherty. 2009. Flavour or forethought: Tūhoe traditional management strategies for the conservation of kererū (Hemiphaga novaeseelandiae novaeseelandiae) in New Zealand. Ecology and Society 14(1). [online] URL: $\underline{\text { http:// }}$ www.ecologyandsociety.org/vol14/iss 1/art40/

Lyver, P. O'B., J. Davies, and R. B. Allen. 2014. Settling indigenous claims to protected areas: weighing Māori aspirations against Australian experiences. Conservation \& Society 12(1):89-106. http://dx.doi.org/10.4103/0972-4923.132134

Lyver, P. O'B., and J. M. Tylianakis. 2017. Indigenous peoples: conservation paradox. Science 357:141-142. http://dx.doi. org/10.1126/science.aao0780

Mazzochi, F. 2006. Western science and traditional knowledge. EMBO reports 7:463-466. http://dx.doi.org/10.1038/sj.embor.7400693 
Mistry, J., and A. Berardi. 2016. Bridging indigenous and scientific knowledge. Science 352:1274-1275. http://dx.doi. org/10.1126/science.aaf1160

Morunga, K., and B. Tahi. 2013. Industry and people: development in the Tuawhenua. Tūhoe Tuawhenua Trust, Ruatāhuna, New Zealand.

New Zealand Government. 2014. Te Urewera Act 2014. Public Act No. 51. Parliamentary Counsel Office, Wellington, New Zealand.

New Zealand Government. 2016. New Zealand biodiversity action plan. Wellington, New Zealand.

O'Faircheallaigh, C. 2013. Extractive industries and Indigenous peoples: A changing dynamic? Journal of Rural Studies 30:2-30. http://dx.doi.org/10.1016/j.jrurstud.2012.11.003

Pitty, R., and S. Smith, 2011. The indigenous challenge to Westphalian sovereignty. Australian Journal of Political Science 46:121-139. http://dx.doi.org/10.1080/10361146.2010.546336

Raffles, H. 2002. Intimate knowledge. International Social Science Journal 54:325-335. http://dx.doi.org/10.1111/1468-2451.00385

Rathwell, K. J., D. Armitage, and F. Berkes. 2015. Bridging knowledge systems to enhance governance of the environmental commons: a typology of settings. International Journal of the Commons 9:851-880. http://dx.doi.org/10.18352/ijc.584

Raymond, C. M., G. G. Singh, K. Benessaiah, J. R. Bernhardt, J. Levine, H. Nelson, N. J. Turner, B. Norton, J. Tam, and K. M. A. Chan. 2013. Ecosystem services and beyond: using multiple metaphors to understand human-environment relationships. Bioscience 63:536-546. http://dx.doi.org/10.1525/bio.2013.63.7.7

Rights and Resources Initiative. 2015. Who owns the worlds' land? A global baseline of formally recognized indigenous and community land rights. Rights and Resources Initiative, Washington, D.C., USA.

Roberts, M. 2012. Mind maps of the Maori. GeoJournal 77:741751. http://dx.doi.org/10.1007/s10708-010-9383-5

Ruru, J., P. O’B. Lyver, N. Scott, and D. Edmunds. 2017. Reversing the decline in biodiversity: empowering Māori within reformed conservation law. Policy Quarterly 12:65-71.

Smith, L. T. 2012. Decolonizing methodologies: research and indigenous peoples. Second edition. Zed Books, London, UK.

Smyth, D. 2008. Just add water? Taking Indigenous Protected Areas into sea country. In D. Smyth and G. Ward, editors. Protecting country: indigenous governance and management of protected areas. AIATSIS, Canberra, Australia.

Stevenson, M. G. 2006. The possibility of difference: rethinking co-management. Human Organization 65:167-180. http://dx.doi. org/10.17730/humo.65.2.b2dm8thgb7wa4m53

Stocker, L., L. Collard, and A. Rooney. 2016. Aboriginal views and colonisation: implications for coastal sustainability. Local Environment 21:844-865. http://dx.doi.org/10.1080/13549839.20$\underline{15.1036414}$

Tauli-Corpuz, V. 2016. Rights of indigenous peoples. Report on the Special Rapporteur of the Human Rights Council of the rights of indigenous peoples. A/71/229, 29 July 2016, 71st Session of United Nations General Assembly, United Nations, New York, USA.

Telfer, W. R., and M. J. Garde 2006. Indigenous knowledge of rock kangaroo ecology in Western Arnhem Land, Australia. Human Ecology 34:379-406. http://dx.doi.org/10.1007/s10745-006-9023-3

Tengö, M., E. S. Brondizio, T. Elmqvist, P. Malmer, and M. Spierenburg. 2014. Connecting diverse knowledge systems for enhanced ecosystem governance: the multiple evidence base approach. AMBIO 43:579-591. http://dx.doi.org/10.1007/ $\underline{\mathrm{s} 13280-014-0501-3}$

Tengö, M., R. Hill, P. Malmer, C. M. Raymond, M. Spierenburg, F. Danielsen, T. Elmqvist, and C. Folke. 2017. Weaving knowledge systems in IPBES, CBD and beyond-lessons learned for sustainability. Current Opinion in Environmental Sustainability 26-27:17-25. http://dx.doi.org/10.1016/j.cosust.2016.12.005

Tester, F. J., and P. Irniq. 2008. Inuit Qaujimajatuqangit: social history, politics and the practice of resistance. Arctic 61:48-61.

Turner, N. J., R. Gregory, C. Brooks, L. Failing, and T. Satterfield. 2008. From invisibility to transparency: identifying the implications. Ecology and Society 13(2):7. http://dx.doi. org/10.5751/ES-02405-130207

van Egmond, N. D., and H. J. M. de Vries. 2011. Sustainability: the search for the integral worldview. Futures 43:853-867. http:// dx.doi.org/10.1016/j.futures.2011.05.027

Van Opstal, M., and J. Hugé. 2013. Knowledge for sustainable development: a worldviews perspective. Environment, Development and Sustainability 15:687-709. http://dx.doi.org/10.1007/ $\underline{\mathrm{s} 10668-012-9401-5}$

Venn, T. J., and J. Quiggan. 2007. Accommodating indigenous cultural heritage values in resource assessment: Cape York Peninsula and the Murray-Darling Basin, Australia. Ecological Economics 61:334-344. http://dx.doi.org/10.1016/j.ecolecon.2006.03.003

Vidal, C. 2008. Wat is een wereldbeeld? (What is a worldview?). In $\mathrm{H}$. Van Belle and J. Van der Veken, editors. Nieuwheid denken. De wetenschappen en het creatieve aspect van de werkelijkheid, Acco, Leuven.

Walsh, F. J., P. V. Dobson, and J. C. Douglas. 2013. Anpernirrentye: a framework for enhanced application of indigenous ecological knowledge in natural resource management. Ecology and Society 18(3):18. http://dx.doi.org/10.5751/ES-05501-180318

Wehi, P. M. 2009. Indigenous ancestral sayings contribute to modern conservation partnerships: examples using Phormium tenax. Ecological Applications 19:267-275. http://dx.doi. org/10.1890/07-1693.1

West, P., J. Igoe, and D. Brockington. 2006. Parks and peoples: the social impact of protected areas. Annual Review of Anthropology 35:251-277. http://dx.doi.org/10.1146/annurev. anthro.35.081705.123308 